\title{
FUGE FUN UPAYA PENGENALAN MAKANAN BERGIZI DAN PENINGKATAN KREATIVITAS ANAK USIA DINI
}

\author{
Ajeng Sri Hikmayani \\ Program Study Pendidikan Anak Usia Dini STKIP Sebelas April Sumedang \\ Email: ajeng.childhood@gmail.com
}

\begin{abstract}
Abstrak
Penelitian ini dilatar belakangi adanya temuan masalah kemampuan anak memilih, mengkonsumsi makanan bergizi serta perkembangan kreativitas anak di Kelompok B TK Wijaya Kusumah yang memfokuskan pada kegiatan makanan tambahan yang kurang variatif, belum mesntimulus anak senang buah dan sayur. Dalam Aspek perkembangan kreativitas kegiatan menggambar, mewarnai, dan terbatasnya alat sumber pembelajaran untuk penunjang pembelajaran kreativitas. Penelitian ini bertujuan untuk mengetahui upaya meningkatkan kemampuan kreativitas anak melalui kegiatan Fuge Fun. Metode yang digunakan adalah penelitian tindakan kelas (PTK). Pelaksanaan penelitian ini terdiri dari dua siklus. Setiap siklus dilakukan 2 tindakan. Jumlah anak yang diberikan tindakan berjumlah 21 anak. Hasil observasi pra-siklus secara persentase kemampuan pengetahuan makanan bergizi dan kreativitas anak pada ketegori $\mathrm{B}=46,02 \%$, kategori $\mathrm{C}=38,64 \%$, kategori $\mathrm{K}=15,34 \%$. Hasil observasi pasca-siklus mengalami peningkatan pada kemampuan pengetahuan makanan bergizi dan kreativitas melalui kegiatan Fuge Fun secara persentase kategori $\mathrm{B}=84,56 \%$, kategori $\mathrm{C}=15,44 \%$, kategori $\mathrm{K}=0 \%$, Maka dapat disimpulkan kegiatan Fuge Fun dapat meningkatkan perkembangan kreativitas anak. Rekomendasi bagi Sekolah pengadaan referensi untuk penunjang penyusunan bahan ajar, bagi guru mengusahakan untuk menggunakan berbagai media yang dapat menstimulasi tahap perkembangan kreativitas anak serta variatif dalam pemberian makanan pada anak.
\end{abstract}

Kata Kunci : Makanan bergizi, Kreativitas

\begin{abstract}
The background of this research is the finding of the problem of the ability of children to choose, consume nutritious food and the development of creativity in children in TK B Group Wijaya Kusumah that focuses on less varied additional food activities, not yet having a child and fruit vegetable stimulus. In the aspect of development of creativity, drawing activities, coloring, and limited learning resources tools to support creativity learning. This study aims to determine the efforts to improve children's creativity ability through Fuge Fun activities. The method used is classroom action research (CAR). The implementation of this study consisted of two cycles. Each cycle carried out 2 actions. The number of children given an action amounted to 21 children. The pre-cycle observation results in the percentage of nutritional food knowledge and children's creativity in category $B=46.02 \%$, category $C=38.64 \%$, category $K=15.34 \%$. Post-cycle observation results experienced an increase in the ability of knowledge of nutritious food and creativity through Fuge Fun activities in a percentage category $B=84.56 \%$, category $C=$ $15.44 \%, K$ category $=0 \%$. Then it can be concluded that Fuge Fun activities can improve the development of children's creativity. Recommendations for schools to provide references to support the preparation of teaching materials, for teachers to try to use various media that can stimulate the stage of development of children's creativity and variety in feeding children.
\end{abstract}

Keywords: Nutritious food, creativity

(C) 2019 Ajeng Sri Hikmayani Under the license CC BY-SA 4.0

http://jurnal.upmk.ac.id/index.php/pelitapaud 


\section{PENDAHULUAN}

Anak usia dini adalah anak yang berusia 0-6 tahun. Pada usia ini anak perlu distimulus oleh orang tua dan guru agar anak dapat tumbuh dan berkembang secara optimal sesuai usianya. Anak usia dini (AUD) merupakan investasi yang sangat besar bagi keluarga dan bangsa. Anakanak inilah yang akan menjadi penerus bagi keluarga dan tentunya bagi bangsa juga.

Optimalisasi tubuh kembang anak salah satunya dari aspek asupan nutrisi yang dikonsumsi oleh anak sejak dini. Mengenalkan makanan bergizi untuk anak usia dini sangat penting, agar anak mengetahui makanan bergizi dan anak tahu manfaat dari makanan-makanan bergizi tersebut. Tubuh yang sehat merupakan faktor yang sangat penting, karena bila tubuh tidak sehat segala aktivitas akan terganggu, sedangkan bila memiliki tubuh sehat segala aktivitas dapat dikerjakan dengan lancar. Nurheti Yuliarti, (2009, hlm. 34) mengatakan:

"Bila makanan yang dikonsumsi seseorang sudah memenuhi makanan gizi seimbang, cukup berolahraga, cukup beristirahat atau tidur, hidup teratur, tidak stress, bahkan bebas dari cemaran zat polutan (udara, makanan dan air), maka suplemen makanan tentunya tidak dianjurkan untuk dikonsumsi karena kebutuhan gizi sudah dipenuhi dari makanan sehari-hari."

Melalui Pendidikan Anak Usia Dini, anak dikenalkan tentang makananmakanan yang bergizi, agar anak mengetahui makanan yang mengandung gizi, bermanfaat bagi tubuh dan anak juga akan mengetahui mana makanan yang tidak sehat dan mana yang sehat untuk dimakan. Peranan Pendidikan Anak Usia Dini (PAUD) dapat membantu dalam menciptakan kualitas anak dimasa yang akan datang. Permen No.137 Tahun 2014 dalam undang-undang Nomor 20 Tahun 2003 tentang sistem Pendidikan Nasional Pasal 1 angka 14 berbunyi: "Pendidikan Anak Usia Dini (PAUD) adalah suatu upaya pembinaan yang ditujukan kepada anak sejak lahir sampai dengan usia enam tahun yang dilakukan melalui pemberian ransangan pendidikan untuk membantu pertumbuhan dan perkembangan jasmani dan rohani agar anak memiliki kesiapan dalam memasuki pendidikan lebih lanjut". Dengan demikian, dapat disimpulkan bahwa pendidikan anak usia dini merupakan tahap awal dimana anak perlu dididik dan diberi tahu mengenai bahaya banyak makan jajanan-jajanan snack. Anak perlu dibekali pengetahuan bagaimana mengenal makanan dan minuman yang sehat. Dengan bekal pengetahuan itu, anak siap memilah dan 
memilih makanan dan minuman yang akan dikonsumsinya.

Pembelajaran Fruit-Vegetable Fun yang kemudian disingkat Fuge Fun bentuk pengenalan makanan bergizi disekolah yang diharapkan memberikan peran penting untuk pengetahuan dan pengaruh pola hidup sehari-hari anak usia dini. Melalui Fuge Fun pengenalan makanan bergizi dapat membiasakan peserta didik untuk mengkonsumsi makanan bergizi setiap hari dan menstimulus kreativitas anak karena dalam pembelajarannya melibatkan anak untuk hand on experience. Berdasarkan hasil observasi Taman kanak-kanak pembelajaran pengenalan makanan bergizi melalui program pemberian makan tambahan pada anak dilaksanakan satu seminggu sekali atau bahkan satu bulan satu kali. Peneliti belum melihat satu kaitan antara program pemberiam makanan tambahan dengan program kegiatan pembelajaran yang akan dilakukan guru. Hali ini apabila mengacu pada kurikulum Holistik Integratif maka menjadi satu kesatuan yang utuh sebagai lembaga pendidikan anak usia dini yang menyelenggarakan pengasuhan, pendidikan, kesehatan, gizi anak. Mengenalkan makanan bergizi guru cenderung menggunakan media-media gambar yang kurang menarik untuk anak.
Peneliti berharap guru bisa mengenalkan makanan bergizi dengan menggunakan media nyata seperti sayur dan buah-buahan dan sejenisnya yang tergolong makanan bergizi dan menjelaskan vitamin yang ada didalamnya dan manfaatnya untuk tubuh dan kecerdasan supaya anak mengenal dan mau memakan makanan bergizi setiap hari yang sudah dibawanya dan anak tidak membawa bekal-bekal berupa snack dan sejenisnya. Pentingnya anak-anak mengetahui manfaatnya dalam menjaga badan yang sehat, tumbuh dan berkembang dengan baik. Oleh karena itu maka penelitian ini difokuskan pada Fuge Fun upaya pengenalan makanan bergizi dan peningkatan kreativitas pada anak.

Secara umum tujuan penelitian ini adalah mengetahui sejauh mana peningkatan kemampuan anak dalam pemilihan makanan bergizi melalui kegiatan Fuge Fun, dan mengetahui sejauh mana peningkatan kemampuan kreativitas anak melalui kegiatan Fuge Fun.

Dalam pemberian makanan bergizi, orang tua sangat berperan penting untuk pertumbuhan dan perkembangan anak, selain itu pemberian makanan bergizi juga penting untuk kesehatan anak. Semestinya anak mendapatkan makanan yang bergizi dari prinsip 4 sehat 5 sempurna (nasi, laukpauk, sayur-mayur, buah-buahan, dan 
susu). Oleh sebab itu makanan yang seimbang bagi kebutuhan anak, seimbang nutrisi dan nilai gizinya (Astuti, 2016, hlm. 265). Mendapatkan makanan lengkap dan seimbang mulai dari karbohidrat yang didapat dari beras dan tepung, protein dari daging dan ikan, sayuran yang banyak mengandung serat, dan buah-buahan yang kaya vitamin. Makanan itu terdiri atas bagian-bagian yang berbentuk ikatanikatan kimia atau unsur-unsur anorganik disebut zat-zat makanan atau zat gizi/nutrient Santoso (2008). Sedangkan menurut Murtie (2014) makanan adalah bentuk makanan yang terbuat dari bahanbahan makanan dan dimasukkan ke dalam tubuh melalui mulut kemudian melalui proses pencernaan.

Sedangkan zat gizi (nutriens) adalah ikatan kimia yang diperlukan tubuh untuk melakukan fungsinya, yaitu menghasilkan energi, membangun dan memelihara jaringan serta mengatur proses-proses kehidupan. Santoso (2008) mengemukakan zat gizi adalah zat penyusun bahan makanan yang diperlukan oleh tubuh untuk metabolise, zat makanan yang mengandung zat gizi yaitu air, protein, lemak, karbohidrat, vitamin dan mineral. Astuti (2016) mengatakan makanan bergizi adalah makanan yang berasal secara alami, tidak adanya bahan kimia atau bahan lainnya yang dapat membahayakan tubuh, mengandung berbagai unsur-unsur terpenting yang di butuhkan di dalam tubuh, seperti karbohidrat, mineral, protein, vitamin, lemak, dan air.

Program Pendidikan Gizi Menurut Contento (2011, hlm 22), intervensi dan strategi program pendidikan gizi bertujuan untuk meningkatkan motivasi, kemampuan dan kesempatan untuk makan sehat dan hidup secara aktif, sebagaimana diungkapkannya: "Effective interventions and strategies are those that enhance people's motivation, ability, and opportunities to eat well and live actively". Program pendidikan gizi merupakan upaya untuk membantu individu agar kritis terhadap makanan. Perilaku kritis ini mencakup kemampuan afektif seperti ketegasan, manajemen diri dan kemampuan untuk mengontrol pemilihan makanan (Contento, 2011, hlm 14). Program pendidikan gizi pada dasarnya berfokus pada makan dan makanan, memahami perilaku individu dan perilaku dalam konteks sosial. Dengan demikian penting untuk memahami faktor yang berpengaruh terhadap keputusan makan baik individu maupun komunitas (Contento, 2011, hlm 15).

Anak Usia Dini 4-6 tahun adalah masa pertumbuhan yang cepat dan kegiatan fisik yang aktif. Keturunan dan 
lingkungan merupakan determinan yang sangat penting dalam pertumbuhan dan perkembangan sekolah anak. Penyebab langsung seorang anak dapat tumbuh dan berkembang secara baik adalah cukupnya masukan gizi serta terbebasnya dari penyakit infeks.

Kreativitas mengandung beberapa definisi. Lawrence (Suratno, 2003, hlm. 24) menyatakan kreativitas merupakan ide atau pikiran manusia yang bersifat inovatif, berdaya guna, dan dapat dimengerti, sehingga hasil pikiran anak yang baru merupakan bentuk kreativitas dari individu anak. Sujiono (2005, hlm. 134) meyakini bahwa kreativitas yang ditunjukkan anak merupakan bentuk kreativitas yang original dengan frekuensi kemunculannya seolah tanpa terkendali.

Kreatif merupakan suatu sifat yang dimiliki oleh seseorang yang mempunyai kreativitas. Hal ini dikarenakan hanya orang kreatif yang mempunyai ide gagasan kreatif dan original. Orang akan menjadi kreatif apabila distimulasi sejak dini. Anak dikatakan kreatif apabila mampu menghasilkan produk secara kreatif serta tidak tergantung dengan orang lain yang berarti bahwa dalam memuaskan diri bukan karena tekanan dari luar. Amabile (Suratno, 2005, hlm. 10) menjelaskan bahwa motivasi dalam diri atau intrinsik tercipta dengan sendirinya dan mendorong timbulnya kreativitas. Dan itu akan berlangsung dalam kondisi mental tertentu.

Muharam (Munandar, 2009, hlm. 28) menyatakan bahwa kreativitas dapat dibedakan menjadi tiga pengertian, yaitu: Pertama, kemampuan untuk membuat kondisi baru, berdasarkan data, informasi, dan unsur-unsur yang ada (daya cipta). Kedua, kemampuan menggunakan data atau informasi yang tersedia. Ketiga, kemampuan yang mencerminkan kelancaran, keluwesan, kemurnian (orisinal) dalam mengembangkan dan memperkaya gagasan. Secara khusus, kreativitas berkarya senirupa diartikan sebagai kemampuan menemukan, mencipta, membuat, merancang ulang, dan memadukan suatu gagasan baru maupun lama menjadi kombinasi baru yang divisualkan ke dalam komposisi suatu karya senirupa dengan didukung kemampuan terampil yang dimilikinya. Biasanya orang mengartikan kreativitas sebagai daya cipta yaitu sebagai kemampuan untuk menciptakan hal-hal baru.

Kreativitas sesungguhnya tidak perlu hal-hal yang baru sama sekali, tetapi merupakan gabungan (kombinasi) dari hal-hal yang sudah ada sebelumnya yaitu berdasarkan informasi, data atau 
pengalaman yang telah diperoleh seseorang selama hidupnya (Munandar, 2009, hlm. 47). Semakin banyak pengalaman dan pengetahuan yang dimiliki makin besar kemungkinan seseorang memanfaatkan pengalaman dan pengetahuan tersebut untuk bersibuk diri secara kreatif.

Dari paparan tersebut dapat disimpulkan bahwa kreativitas adalah suatu kemampuan untuk menghasilkan gagasan baru, memecahkan masalah, dan ide serta mempunyai maksud dan tujuan yang ditentukan. Kreativitas dalam bidang seni diartikan sebagai berkarya yaitu suatu kemampuan untuk mewujudkan karya seni sebagai hasil kreativitasnya. Kreativitas dalam penelitian ini adalah suatu kemampuan yang ditandai dengan empat aspek kreativitas: kelancaran (fluency), keluwesan (flexibility), keaslian (originality), dan elaborasi (elaboration).

Memahami keberadaan anak dalam pengembangan kreativitas perlu diperhatikan. Kreativitas dalam penelitian ini dikembangkan melalui aktivitas membentuk aneka buah-buahan dengan sajian yang lebih menarik. Untuk memahami kreativitas anak perlu diperhatikan karakteristik tindakan anak secara umum yang menunjukkan kreativitas.
Torrance (Suratno, 2005, hlm. 11) menyebutkan karakteristik tindakan anak yang menunjukkan kreativitas adalah sebagai berikut; 1) Belajar kreatif, 2) Rentang perhatian panjang, 3) Mampu mengorganisasikan yang menakjubkan, 4) Dapat kembali kepada sesuatu yang sudah dikenalnya dan melihat dari cara yang berbeda, 5) Belajar banyak melalui fantasi dan memecahkan permasalahan dengan menggunakan pengalamannya, Menikmati permainan dengan kata-kata dan tempat sebagai pencerita yang alami.

Peningkatan kreativitas dapat dilakukan dengan berbagai macam kegiatan eksperimen dan eksplorasi yang dapat dilakukan oleh anak. Tugas guru, orang tua, dan orang-orang yang dekat dengan anak perlu memahami bagaimana memfasilitasi anak agar kreativitas itu muncul sebagai kekuatan yang sangat diperlukan bagi kehidupannya kelak. Ciri-ciri Kreativitas Anak menurut pendapat Munandar (2009, hlm. 71) meliputi rasa ingin tahu yang luas dan mendalam, sering mengajukan pertanyaan yang baik, memberikan banyak gagasan atau usul terhadap suatu masalah, bebas dalam menyatakan pendapat, mempunyai rasa keindahan yang dalam, menonjol dalam salah satu bidang seni, mampu melihat suatu masalah dari berbagai 
segi/sudut pandang, mempunyai rasa humor yang luas, mempunyai daya imajinasi, orisinal dalam ungkapan gagasan dan dalam pemecahan masalah.

Ciri-ciri kreativitas anak dapat diketahui melalui pengamatan terhadap perilaku anak yang berbeda dengan anak pada umumnya. Perbedaan perilaku anak tersebut biasanya membuat orangtua cemas dan bagi orangtua yang belum memahami tentang ciri-ciri anak kreatif biasanya menganggap sebagai anak nakal. Bakat dalam bentuk kreativitas akan tumbuh dan berkembang jika didukung dengan fasilitas dan kesempatan yang memungkinkan. Orang tua dan guru harus menyadari keragaman bakat dan kreativitas anak. Cara mendidik dan mengasuh anak harus disesuaikan dengan pribadi dan kecepatan masing-masing anak, sehingga tidak ada penekanan atau paksaan dalam mendidik anak. Penerapan pendekatan 4 P (Pribadi, Pendorong, Proses, dan Produk) dalam mengembangkan kreativitas menurut Munandar (2009, hlm. 89) dapat mempengaruhi perilaku anak dalam menampilkan ciri-ciri pribadi kreatif.

Keempat segi tersebut dapat diuraikan sebagai berikut.

Segi pribadi, kreativitas adalah hasil keunikan pribadi dalam berinteraksi dengan lingkungan dan merupakan penggambaran adanya berbagai ciri khusus dalam tiap individu. Cirinya antara lain berupa rasa ingin tahu, mempunyai minat yang luas, berani mengambil resiko, mempunyai prakarsa, kepercayaan diri, tekun, dan ulet dalam mengerjakan tugas yang diminati dan diyakini.

Segi pendorong, merupakan suatu kondisi yang memotivasi seseorang pada perilaku kreatif. Pendorong kreativitas ini dapat berupa hasrat yang kuat pada diri individu dan dapat pula berupa penghargaan dari orang lain (orangtua, guru), serta tersedianya sarana dan prasarana penunjang sikap kreatif.

Segi proses, kreativitas adalah hasil dari tahapan pengalaman seseorang dalam melakukan suatu pekerjaan atau kegiatan. Kreativitas ditinjau dari segi proses yaitu sebagai suatu kemampuan untuk membentuk kombinasi-kombinasi baru dari dua konsep atau lebih yang sudah ada dalam pikiran.

Segi produk, kreativitas adalah kemampuan untuk mencipta atau menghasilkan produk-produk baru atau kombinasi dari hal sebelumnya yang sudah ada. Produk tersebut dapat berupa ide-ide baru, penemuan-penemuan baru, maupun teknologi baru yang memungkinkan manusia dapat meningkatkan kualitas hidupnya. 
Karakteristik kreativitas anak dalam penelitian ini adalah kreativitas yang menunjukkan kelancaran dan keaslian anak dalam menyajikan aneka buahbuahan. Kreativitas anak yang menunjukkan kelancaran anak dalam menceritakan hasil karyanya. Kreativitas anak yang menunjukkan keaslian ide atau gagasan anak dalam menyajikan aneka buah-buahan yang telah disediakan, dan kreativitas anak yang dilihat dari elaborasi atau penjelasan anak mengenai pengembangan ide anak dari hasil penyajian yang telah dibuatnya.

Perkembangan kreativitas mengikuti pola yang dapat diramalkan, pertama-tama terlihat dalam permainan anak, lalu secara bertahap menyebar ke berbagai bidang kehidupan lainnya seperti pekerjaan sekolah, kegiatan rekreasi dan pekerjaan. Hasil kreatif biasanya mencapai puncaknya pada usia tiga puluh dan empat puluhan. Setelah itu tetap mendatar atau secara bertahap menurun.

Apakah pola ini akan diikuti atau tidak sebagian besar tergantung pada pengaruh-pengaruh lingkungan yang memudahkan atau menghalangi ekspresi kreativitas. Spock (dalam Hurlock, 1999) menekankan betapa pentingnya sikap awal orang tua terhadap ekspresi kreativitas anak.
Beberapa cara yang paling umum digunakan anak untuk mengekspresikan kreativitas pada berbagai usia dijelaskan oleh Hurlock (1999), sebagai berikut: Animisme adalah kecenderungan untuk menganggap benda mati sebagai benda hidup. Anak kecil mempunyai pengetahuan dan pengalaman yang terlalu minim untuk mampu membedakan antara hal-hal yang mempunyai sifat hidup dan yang tidak. Pikiran animistik dimulai sekitar usia anak 2 tahun, mencapai puncaknya antara 4 dan 5 tahun, kemudian menurun dengan cepat dan menghilang segera sesudah anak masuk sekolah. Semua anak mempunyai potensi untuk kreatif, walaupun tingkat kreativitasnya berbeda-beda. Akibatnya, kreativitas seperti halnya setiap potensi lain, perlu diberi kesempatan dan rangsangan oleh lingkungan untuk berkembang. Titik pandangan baru mengenai kreativitas mendorong diadakannya penelitian untuk menentukan apa saja kondisi lingkungan yang menguntungkan dan membekukan perkembangan kreativitas.

Penelitian telah menunjukkan dua faktor yang penting (Hurlock, 1999). Pertama, sikap sosial yang ada dan tidak menguntungkan kreativitas harus ditanggulangi. Alasannya, karena sikap seperti itu mempengaruhi teman sebaya, orang tua dan guru serta perlakuan mereka 
terhadap anak yang berpotensi kreatif. Apabila harus dibentuk kondisi yang menguntungkan bagi perkembangan kreativitas, faktor negatif ini harus dihilangkan. Kedua, kondisi yang menguntungkan bagi perkembangan kreativitas harus diadakan pada awal kehidupannyua ketika kreativitas mulai berkembang dan harus dilanjutkan terus sampai berkembang dengan baik.

Banyak hal dapat dilakukan untuk meningkatkan kreativitas, seperti memberi dorongan kreatif, waktu untuk bermain dan sebagainya. Anak membutuhkan waktu dan kesempatan menyendiri untuk mengembangkan kehidupan imajinatif yang kaya. Selain hal tersebut mereka juga membutuhkan sarana untuk bermain dan kelak sarana lainnya harus disediakan untuk merangsang dorongan eksperimental dan eksplorasi, yang merupakan unsur penting dari semua kreativitas dengan dukungan lingkungan yang merangsang.

Tentang kondisi lingkungan yang dapat merangsang kreativitas dijelaskan oleh Hurlock (1999) bahwa lingkungan rumah dan sekolah harus merangsang kreativitas dengan memberikan bimbingan dan dorongan untuk menggunakan sarana yang akan mendorong kreativitas. Kurangnya rangsangan, sebagai salah satu hambatan yang paling umum terjadi, akan menghambat perkembangan kreativitas dan membekukan kreativitas itu sendiri. Kurangnya rangsangan dapat disebabkan ketidaktahuan orang tua dan orang lain dalam lingkungan anak tentang pentingnya kreativitas atau mungkin ditimbulkan oleh asumsi bahwa kreativitas merupakan sifat bawaan, sehingga alam akan mengatur perkembangnnya dan karena nya rangsangan tidak diperlukan.

\section{METODE PENELITIAN}

\section{Jenis Penelitian}

Metode yang digunakan dalam penelitian ini adalah Penelitian Tindakan Kelas (Classroom Action Research). Implikasi dalam penelitian tindakan ini dilakukan secara kolaborasi artinya peneliti dapat berkolaborasi atau bekerjasama dengan guru TK Wijaya Kusumah sebagai mitra dalam penelitian yang bertujuan untuk membantu meningkatkan pembelajaran yang variatif di kelas serta meningkatkan kualitas kemampuan visual spasial anak kelompok B. Maka penelitian tindakan kelas ini bersifat partisipasif dan kolaboratif.

\section{Desain Penelitian}

Pendekatan yang digunakan dalam penelitian ini adalah penelitian kualitatif untuk mengetahui kondisi dan temuantemuan yang ada di lapangan yaitu dengan desain siklus dengan 2 siklus (dalam 1 siklus melaksanakan 2 tindakan). 
Penelitian tindakan kelas yang akan dilaksanakan mengikuti tahapan desain penelitian Kurt Lewin. Konsep pokok penelitian tindakan Model Kurt Lewin terdiri dari empat komponen, yaitu; a) perencanaan (planning), b) tindakan (acting), c) pengamatan (observing), dan d) refleksi (reflecting). Hubungan keempat komponen tersebut dipandang sebagai siklus yang dapat digambarkan sebagai berikut :

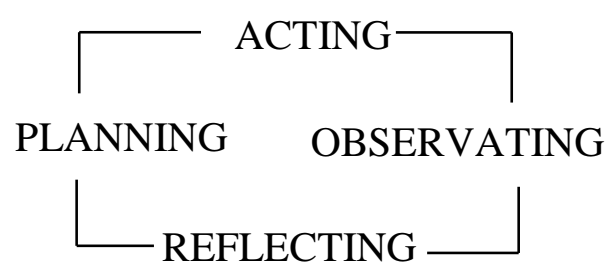

Gambar 1

Desain Model Kurt Lewin

Tahap-tahap di atas, yang membentuk satu siklus dapat dilanjutkan ke siklus berikutnya dengan rencana, tindakan, pengamatan, dan refleksi ulang berdasarkan hasil yang dicapai pada siklus sebelumnya. Maka gambar 3.1 dapat dikembangkan menjadi gambar 3.2.

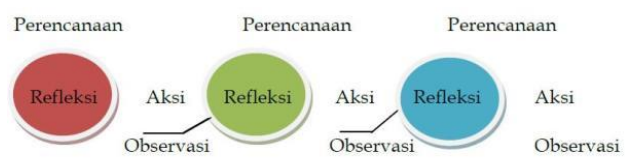

Gambar 2

Model Dasar Desain Tindakan Kurt Lewin yang Dikembangkan

\section{Analisis Data}

Miles dan Huberman (Agusta, 2003, hlm. 10) mendefinisikan penyajian data adalah kegiatan ketika sekumpulan informasi disusun, sehingga memberi kemungkinan akan adanya penarikan kesimpulan dan pengambilan tindakan. Bentuk penyajian data kualitatif berupa teks naratif : berbentuk catatan lapangan; matriks, grafik, jaringan dan bagan. Berdasarkan pemaparan teknik analisis data Miles dan Huberman, maka peneliti dalam menganalisis data menggunakan teknik data analisis interaktif.

\section{Subjek Penelitian}

Subjek Penelitian adalah siswa kelas B usia 5-6 tahun Kelas Abu Bakar. Terdiri dari 21 siswa. Laki-laki 8 anak, perempuan 13 anak di TK Wijaya Kusumah Jl.Citopeng No. 262 RT 1 RW 22 Kelurahan Melong Kecamatan Cimahi Selatan.

\section{HASIL PENELITIAN DAN PEMBAHASAN}

Anak usia kelompok B masanya untuk dirangsang pertumbuhan tubuh dan perkembangan otak melalui salah satunya kegiatan Fuge Fun . Kegiatan ini dapat membantu mengembangkan potensipotensi yang dimiliki anak dalam hal kesabaran, memecahkan masalah, mengetahui pola, mengetahui posisi, 
mengenal dan membuat bentuk, serta imajinasi. Pelaksanaan kegiatan ini harus disesuaikan dengan karakteristik anak sehingga proses pembelajaran berlangsung dengan baik dan memperoleh hasil sesuai harapan. Hasil asesmen awal pengenalan makanan bergizi dan perkembangan kreativitas siswa pada penelitian menunjukan bahwa keduanya masih perlu ditingkatkan. Kemampuan kreativitas yang perlu ditingkatkan antara lain adalah kemampuan dalam mengobservasi bentuk, mengurutkan bentuk sesuai pola, dan membuat kreasi bentuk. Pelaksanaan kegiatan Fuge Fun dibuat beragam dengan pola, bentuk yang berbeda-beda.

Berdasarkan hasil observasi sebelum tindakan terhadap pengenalan pengetahuan makanan bergizi dan kemampuan perkembangan kreativitas anak menunjukkan sebanyak $15,34 \%$ kategori Kurang (K). Pada kategori Cukup (C) sebanyak $38,64 \%$. Sebanyak $46,02 \%$ pada kategori Baik (B). Dari hasil observasi ini menunjukkan bahwa belum setengahnya dari anak didik di kelas B mampu untuk melakukan kegiatan Fuge Fun secara mandiri.

Pada siklus I tindakan I kategori (B) sebesar $62,10 \%$ dan terjadi peningkatan pada tindakan II menjadi 65,70\%. Persentase tindakan I kategori (C) sebesar $33,50 \%$ dan terjadi penurunan pada tindakan II menjadi 30,58\%. Ketegori (K) saat tindakan I sebesar 4,40\% dan pada tindakan II menjadi 3,72\%.. Kegiatan Fuge Fun di siklus II setiap tindakan mengalami peningkatan yang cukup signifikan.

Hasil siklus II tindakan I pada kategori Baik (B) poin yang diperoleh oleh semua anak 246, sedangkan pada tindakan II poin yang diperoleh pada ketegori ini adalah 288. Terlihat adanya peningkatan poin dari tindakan I ke tindakan II pada siklus II. Hasil rekapitulasi observasi pada kategori Cukup (C) poin yang diperoleh oleh semua anak 78, sedangkan pada tindakan II poin yang diperoleh pada ketegori ini adalah 48 . Terlihat dari data di atas ada penurunan poin dari tindakan I ke tindakan II pada siklus II, artinya kemampuan anak yang berada pada kategori cukup (C) sudah berkurang dan meningkat pada kategori baik (B).

Hasil tindakan I pada kategori Kurang (K) poin yang diperoleh oleh semua anak yaitu 0, sedangkan pada tindakan II poin yang diperoleh pada ketegori ini adalah 0 . Data di atas menunjukkan kemampuan anak yang berada pada kategori kurang (K) sudah berkurang dan meningkat pada kategori Cukup (C) dan kategori Baik (B).

Berdasarkan hasil observasi pengenalan pengetahuan makanan bergizi dan perkembangan kreativitas anak, dapat dilihat setelah diberikan perlakuan 
pembelajaran dengan menggunakan kegiatan Fuge Fun setelah tindakan pada kategori Baik (B) sebesar 84,56\%, pada kategori Cukup (C) sebesar 15,44\% (K) yaitu sebesar $0 \%$.

Kegiatan Fuge Fun yang telah diberikan pada proses pembelajaran memberikan manfaat dalam meningkatkan perkembangan kreativitas anak dan pengenalan makanan bergizi anak kelas B TK Wijaya Kusumah. Hal ini terlihat dan dapat dibuktikan melalui data dari hasil observasi selama tindakan siklus I, siklus II serta post test yang dilakukan.

Fuge Fun selain dapat meningkatkan kemampuan kreativitas dan pengetahuan pemilihan makanan begizi pada anak dalam penelitian ini anak dapat terstimulus kemampuan motorik halus yaitu mengkoordinasikan mata dan tangan. Hal ini terlihat saat diminta oleh guru membuat Fuge Fun sesuai keinginan masingmasing, anak-anak antusias membentuk dan menyusun sesuai keinginannya serta senang makan sayuran buah-buahan yang sebelumnya masih sulit.

Berdasarkan penjelasan di atas, secara garis besar kemampuan pengetahuan pemilihan makanan bergizi dan perkembangan kreativitas anak mengalami peningkatan yang baik jika melalui proses belajar yang variatif disertai dengan kondisi pembelajaran yang menyenangkan.

\section{SIMPULAN}

Berdasarkan hasil penelitian mengenai meningkatkan pengetahuan pemilihan makanan bergizi anak dan perkembangan kreativitas anak melalui kegiatan Fuge Fun di TK Wijaya Kusumah J1 Citopeng No 262 Rt 01 Rw 22 Kecamatan Cimahi Selatan dapat disimpulkan bahwa:

Kondisi kemampuan pengenalan makanan bergizi dan perkembangan kreativitas anak di kelas B TK Wijaya Kusumah sebelum diberikan tindakan atau pra-siklus menunjukkan bahwa secara umum kemampuan anak pada kategori Baik (B) sebesar 46,02\%, kategori Cukup (C) sebesar 38,64\%, dan kategori Kurang (K) sebesar 15,34\%. Sehingga dapat disimpulkan bahwa perkembangan kreativitas anak belum banyak terstimulus.

Pengenalan makanan bergizi dan perkembangan kreativitas di Kelas B TK Wijaya Kusumah pasca siklus atau setelah dilakukan tindakan kegiatan Fuge Fun menunjukkan hasil bahwa secara umum pada kategori Baik (B) sebesar 84,56\%, kategori Cukup (C) sebesar 15,44\%, dan kategori Kurang (K) sebesar 0\%. Dengan demikian berdasarkan tindakan yang telah dilakukan terlihat hasilnya pada setiap 
siklus mengalami peningkatan. perkembangan visual spasial anak secara signifikan.

\section{DAFTAR PUSTAKA}

Agusta, I. (2003). "Teknik Pengumpulan dan Analisis Data Kualitatif". Makalah pada pelatihan metode kualitatif di Pusat Penelitian Sosial Ekonomi. Litbang Pertanian, Bogor.

Astuti, A, K. (2016). Perilaku Sehat pada Anak Usia Dini di PAUD Purwomukti Desa Barut Kecamatan Getasan. Scholaria Vol 6 (3) Hlm. 264-272.

Contento, I. (2011). Nutrition Education: Linking Research, Theory, and Practice. Journal of Nutrition Education and Behavior Vol 43 (4) hlm. 10-24.

Hurlock, E.B. (1999). Psikologi Perkembangan: Suatu Pendekatan Sepanjang Rentang Kehidupan. Edisi Kelima. Jakarta: Erlangga

Munandar, S.C. (2009). Kreativitas dan Keberbakatan, Jakarta: Gramedia Pustaka Utama.

Murtie, A. (2014). All About Kesehatan Anak. Jogjakarta: Trans Idea Pulising.

Santoso, S., Anne, L. (2009). Kesehatan dan Gizi. Jakarta: Rineka Cipta.

Sujiono, B; Sujiono, Y,N. (2005). Menu Pembelajaran Anak Usia Dini. Jakarta: Yayasan Citra Pendidikan Indonesia.
Suratno. (2005). Pengembangan Kreativitas Anak Usia Dini. Jakarta: Departemen Pendidikan Nasional.

Undang-Undang Republik Indonesia, No. 20, 2003, Tentang Sistem Pendidikan Nasional. 